\title{
Correction to: Supporting primary school teachers' classroom assessment in mathematics education: effects on student achievement
}

\author{
Michiel Veldhuis ${ }^{1,2} \cdot$ Marja Van den Heuvel-Panhuizen ${ }^{1,3}$ \\ Published online: 15 August 2019 \\ (C) The Author(s) 2019
}

\section{Correction to: Mathematics Education Research Journal https://doi.org/10.1007/s13394-019-00270-5}

Unfortunately, the original version of the article contained an incorrect presentation in the author group due to a mistake made at the Publisher's end. The author Marja van den Heuvel-Panhuizen was previously not included in the first page of the article. The Publisher apologize for this error.

The original article has been corrected.

Publisher's note Springer Nature remains neutral with regard to jurisdictional claims in published maps and institutional affiliations.

The online version of the original article can be found at https://doi.org/10.1007/s13394-019-00270-5

Michiel Veldhuis

m.veldhuis@uu.nl

$1 \quad$ Freudenthal Group, Department of Pedagogical and Educational Sciences, Faculty of Social and Behavioural Sciences \& Freudenthal Institute, Faculty of Science, Utrecht University, PO Box 80140, 3508 Utrecht, TC, Netherlands

2 iPabo University of Applied Sciences, Amsterdam, Netherlands

3 Nord University, Bodø, Norway 